Liu W.F., Antonelli, M., Yang, H. 2017. Towards improvement of grey water footprint assessment: with an illustration for global maize cultivation. Journal of Cleaner Production. 147: 1-9.

\title{
Towards improvement of grey water footprint assessment: with an illustration for global maize cultivation
}

\author{
Wenfeng Liu ${ }^{1}$, Marta Antonelli ${ }^{1}$, Xingcai Liu ${ }^{3}$, and Hong Yang ${ }^{1,2, *}$ \\ 1 Eawag, Swiss Federal Institute of Aquatic Science and Technology, Ueberlandstrasse 133, CH-8600 Duebendorf, \\ Switzerland \\ 2 Department of Environmental Sciences, University of Basel, Petersplatz 1, CH-4003 Basel, Switzerland \\ 3 Key Laboratory of Water Cycle and Related Land Surface Processes, Institute of Geographical Sciences and Natural \\ Resources Research, Chinese Academy of Sciences, Beijing, 100101, China \\ * Corresponding Author: hong.yang@eawag.ch; Tel.: + 4158765 5568; Fax: +41 587655802
}

Abstract: The grey water footprint refers to the volume of water that is required to assimilate polluted water. It reflects the intensity of water pollution caused by water use for human activities. This study aims to address some major shortcomings associated with grey water footprint accounting in the literature and discuss several ways towards its improvement. Global maize production is used for illustration. The study specifically tackles three issues: the appropriate water quality standards for grey water footprint assessment; grey water footprint for multiple pollutants; and the influence of spatial resolution of the assessment on the level of grey water stress. A biophysical crop model is applied to quantify nitrogen and phosphorus losses to water in maize production on a global scale with a 0.5 degree spatial resolution. The study shows that the grey water footprint calculation is highly sensitive to the water standards applied. The results also suggest that the grey water footprint relating to nitrogen and phosphorus pollution caused by maize production alone has already exceeded their local water availability in many parts of the world. Grey water stress shows a more critical situation at the grid level than at the watershed level for maize cultivation because the former represents the local concentration whereas the latter gives the average situation of the whole watershed. This study highlights the need for standardizing the setting of water quality standards for a consistent grey water footprint assessment taking into consideration the diverse aquatic ecosystems and ambient water quality requirements across regions, as well as the presence of multiple pollutants in water bodies.

Keywords: nitrogen and phosphorus losses; water quality standards; grey water stress; global assessment; PEPIC

This document is the accepted manuscript version of the following article: Liu, W., Antone11i, M., Liu, X., \& Yang, H. (2017). Towards improvement of grey water footprint assessment: with an illustration for global maize cultivation. Journal of cleaner Production, 147, 1-9. https://doi.org/10.1016/j.jclepro.2017.01.072 


\section{Introduction}

Nitrogen $(\mathrm{N})$ and phosphorus $(\mathrm{P})$ are key elements to life and are essential for crop and livestock production. During the period 1960-2010, the application of N and P fertilizers in agriculture for food production increased nine-fold and three-fold, respectively (Sutton et al., 2013). The use of fertilizers has, on the one hand, improved agricultural productivity, enabling the feeding of a growing world population while coping with the dietary shift towards an increased consumption of meat and dairy products. On the other hand, the use of fertilizers has dramatically increased the amount of $\mathrm{N}$ and P entering the terrestrial biosphere (Bennett et al., 2001; Vitousek et al., 2009). Nutrient losses from croplands into water bodies have caused major environmental problems, such as water quality degradation, groundwater contamination, biodiversity loss, fish deaths, and eutrophication (Galloway and Cowling, 2002; Obersteiner et al., 2013; Vitousek et al., 1997).

The need to account for the impacts of agricultural production in terms of water quantity and quality led to the development of water footprint indicators in the early 2000s (Hoekstra, 2003). The water footprint (WF) is a multidimensional indicator of consumptive water use, which accounts for green (rain) water, blue (surface and underground) water resources, and grey (polluted) water. The grey water footprint (GWF) was introduced by Hoekstra and Chapagain (2008) as a measure of the intensity of water pollution caused by water use for human activities. It is defined as the volume of water that is required to assimilate a load of pollutants to a freshwater body, based on natural background concentrations and existing ambient water quality standards (Hoekstra et al., 2011). The idea of measuring water pollution in terms of the amount of water needed to dilute pollutants can be traced back to Falkenmark and Lindh (1974), who pointed out that the amount of water required to dilute pollutants to acceptable levels is about 10-50 times the wastewater flow. The GWF indicator assumes that the gap between a water quality standard and the natural background concentration in a given water body can be used to dilute the pollution loads to meet the water quality standard. It expresses water pollution in terms of a water volume needed to dilute contaminated water to a given quality standard, so that it can be compared with water consumption.

A growing number of studies have provided GWF assessments at various geographical levels. Global GWF assessments have mainly been provided by the Water Footprint Network, e.g., 
Chapagain et al. (2006), Hoekstra and Mekonnen (2012), and Liu et al. (2012) (Table 1). Other GWF studies have been conducted at the national and regional levels (e.g., Cazcarro et al., 2016; Mekonnen et al., 2016); the river basin level (e.g., Miguel Ayala et al., 2016; Vanham and Bidoglio, 2014; Zhi et al., 2015); the city level (e.g., Manzardo et al., 2016a; Wang et al., 2013); and with a focus on specific products or crops (e.g., Ene et al., 2013; Lamastra et al., 2014; Suttayakul et al., 2016). GWF assessments have overwhelmingly been focused on N-related loads to freshwater. Only a few considered multiple pollutants, such as $\mathrm{N}, \mathrm{P}, \mathrm{COD}$ (chemical oxygen demand), and $\mathrm{NH}_{4}$ (ammonium) (Dabrowski et al., 2009; Lu et al., 2016; Pellicer-Martinez and Martinez-Paz, 2016). Most GWF assessments used the drinking water standards (e.g., Bulsink et al., 2010; Chapagain et al., 2006; Mekonnen and Hoekstra, 2011, 2010), with a few exceptions that have used ambient water quality standards (e.g., Pellegrini et al., 2016; Pellicer-Martinez and Martinez-Paz, 2016; Zhuo et al., 2016) (Table 1).

It has been shown that agriculture, mainly cereal production, accounts for $75 \%$ of the global GWF related to anthropogenic $\mathrm{N}$ loads, with the highest contribution from Asia (Mekonnen and Hoekstra, 2015). In the period 1996-2005, GWF accounted for 15\% of the global annual total water footprint (green, blue, and grey), and for 19\% of global agricultural and industrial virtual water flows (Hoekstra and Mekonnen, 2012). It has also been shown that about two-thirds of world's major rivers, especially in tropical and sub-tropical areas, have a pollutant load that exceeds the basin's assimilation capacity (Liu et al., 2012). A number of studies have shown that large GWF can exacerbate water scarcity conditions (Liu et al., 2012; Mekonnen et al., 2016; Zhuo et al., 2016). Others have pointed out that the international trade of agricultural products has resulted in a globalization of agricultural pollution, which has substantially increased over the past few decades (Galloway et al., 2008; Mekonnen et al., 2016; O'Bannon et al., 2014).

The GWF indicator has been developed to describe water quality conditions and inform policies related to water pollution. However, the concept has a number of limitations that are mainly related to three aspects. First, there are significant disparities in the water standards for natural nutrient and maximum allowable concentration values used in the GWF assessment. The volume of GWF and associated values are highly sensitive to the standards chosen. This point has not been paid sufficient 
attention in the GWF studies and confusion often occurs. Second, GWF is generally assessed for individual pollutants, while in reality they mostly co-exist. There has been no study that specifically discussed the influences of the integration of GWF of multiple pollutants on GWF by comparing with individual pollutants. Third, the GWF studies have been conducted at different geographical levels, e.g., grid and river basin levels. However, the effects of different spatial resolutions on the GWF assessment have not been addressed. These shortcomings need to be addressed to enhance the usefulness of GWF assessment as a tool for informing sound water management and policy.

The grey water stress (GWS), which is defined as the ratio of GWF to the actual runoff with the same spatiotemporal scale, indicates the status of the assimilative capacity of the corresponding water body under the pressure of GWF, i.e. the water stress caused by GWF. The concept suggests that if the pressure of GWF is higher than the assimilation capacity, then the GWF is environmentally unsustainable (Hoekstra et al., 2011; Mekonnen et al., 2016). It should be noted that Hoekstra et al. (2011) called this indicator the water pollution level (WPL), which was adopted by several studies (e.g., Liu et al., 2012; Mekonnen and Hoekstra, 2015). However, the concept of GWS is considered to be more explicitly in line with the concept of GWF. Therefore, this terminology is used in this study. To address the above limitations in GWF accounting, a global assessment of the GWF for one of the most important cereal crops in the world, i.e. maize, is conducted for illustration. Globally, maize produces the highest crop production and ranks third on $\mathrm{N}$ and $\mathrm{P}$ consumption as well as the resulted water pollution, following wheat and rice (West et al., 2014). Considering its wide spatial coverage (Portmann et al., 2010) and relatively less diverse production conditions compared to wheat and rice, maize is selected as an illustration here. A large-scale crop model PEPIC (Liu et al., 2016b), i.e. Environmental Policy Integrated Climate (EPIC) under the Python environment (www.python.org), is applied to quantify the losses of $\mathrm{N}$ and $\mathrm{P}$ from fertilizer application on a global scale with a 0.5 degree spatial resolution. Total losses of $\mathrm{N}$ and $\mathrm{P}$ from maize croplands into water bodies are considered in the GWF assessment, as they are the major nutrients applied to crops as agrochemical fertilizers. Water quality standards are clarified and the implications of the disparities are addressed. The GWS is assessed at the grid and river basin levels to highlight the impacts of different geographical scales on the assessment. Given the importance and increasing emphasis of water 
management at the basin/watershed level, it is useful to provide the assessment of GWS at this level.

\section{Methodology and data}

\subsection{Model description and input data}

In this study, the EPIC model (Williams et al., 1984) was used to quantify the $\mathrm{N}$ and P losses from maize production. EPIC is a field-scale crop model, which was initially developed to simulate the impacts of soil erosion on soil productivity. It was then extended to simulate the complex processes in the soil-water-climate-management systems (Williams, 1995). PEPIC is a simulation framework, which is able to prepare spatial input data for EPIC, run the EPIC model, extract outputs of the simulation, and finally map the results of desired variables (Liu et al., 2016b). It has been successfully used to investigate the crop-water relations of maize and assess global $\mathrm{N}$ losses from major crops (Liu et al., 2016b, 2016c).

The inputs to the PEPIC model include climate, soil, digital elevation model (DEM), slope, and crop management information, e.g., planting and harvesting dates, irrigation, and fertilizer. The fertilizer inputs (including $\mathrm{N}$ and $\mathrm{P}$ ) were downloaded from EarthStat (http://www.earthstat.org/). This dataset was based on Mueller et al. (2012) and West et al. (2014). Information about the other inputs can be found in (Liu et al., 2016b).

The inputs of $\mathrm{N}$ considered in this study include chemical fertilizer, manure, precipitation deposition, and crop residue decomposition; while the P inputs include chemical fertilizer, manure, and crop residue decomposition. On the downside, the $\mathrm{N}$ outputs include crop uptake, $\mathrm{N}$ lost to atmosphere through denitrification and volatilization, and $\mathrm{N}$ lost to water bodies through surface runoff, leaching, and bounded with sediments. As for P, the outputting pathway is crop uptake, and losses go into water bodies through surface runoff, leaching, and with sediments. More details of the nutrient dynamics of the EPIC model can be found in Williams (1995) and the calculation of N losses can be found in Liu et al. (2016c). For the calculation of GWF related to N and P, the study focused on the total losses of $\mathrm{N}$ and $\mathrm{P}$ into the water bodies.

\subsection{Grey water footprint and grey water stress}

By definition (Hoekstra et al., 2011), GWF is calculated as: 
$\mathrm{GWF}_{\mathrm{N}}=100 * \mathrm{~L}_{\mathrm{N}} /\left(\mathrm{C}_{\mathrm{max}_{-} \mathrm{N}}-C_{\text {nat_N }}\right)$

$\mathrm{GWF}_{\mathrm{P}}=100 * \mathrm{~L}_{\mathrm{P}} /\left(\mathrm{C}_{\mathrm{max} \_\mathrm{P}}-\mathrm{C}_{\text {nat_P }}\right)$

where $\mathrm{GWF}_{\mathrm{N}}[\mathrm{mm}]$ and $\mathrm{GWF}_{\mathrm{P}}[\mathrm{mm}]$ are the grey water footprint derived from $\mathrm{N}$ and $\mathrm{P}$ loads in water bodies, respectively; $\mathrm{L}_{\mathrm{N}}\left[\mathrm{kg} \mathrm{N} \mathrm{ka}^{-1}\right]$ and $\mathrm{L}_{\mathrm{P}}\left[\mathrm{kg} \mathrm{P} \mathrm{ha}{ }^{-1}\right]$ are the $\mathrm{N}$ and $\mathrm{P}$ concentrations, which can be estimated at different levels, e.g., grid and basin levels, as the ratios of total $\mathrm{N}[\mathrm{kg} \mathrm{N}]$ and P [kg P] loads to the whole areas of the corresponding level; $\mathrm{C}_{\max \_\mathrm{N}}\left[\mathrm{mg} \mathrm{N} \mathrm{L}^{-1}\right]$ and $\mathrm{C}_{\max \_\mathrm{P}}\left[\mathrm{mg} \mathrm{P} \mathrm{L}^{-1}\right]$ are the ambient water quality standards for $\mathrm{N}$ and $\mathrm{P} ; \mathrm{C}_{\text {nat_N }}\left[\mathrm{mg} \mathrm{N} \mathrm{L}^{-1}\right]$ and $\mathrm{C}_{\text {nat_P }}\left[\mathrm{mg} \mathrm{P} \mathrm{L}^{-1}\right]$ are the natural background concentrations of $\mathrm{N}$ and $\mathrm{P}$ in the receiving water body; 100 is for unit transformation. In the literature, for multiple pollutants, the GWF was calculated and presented separately for each pollutant, e.g., N, P, COD, and pesticides in some studies (e.g., Dabrowski et al., 2009; Liu et al., 2016a, 2012). For an individual grid cell or a given water body, e.g., river basin, the GWF under the condition of multiple pollutants (hereby referred to as integrated GWF) should be assessed by choosing the highest GWF deriving from single pollutants (Eq. 3). A summation of GWF of individual pollutants would overestimate the total GWF because the volume of water required for diluting one pollutant can simultaneously dilute other pollutants. The highest GWF of a single pollutant can thus represent the integrated GWF for that grid cell or corresponding water body. The integrated grey water footprint is calculated as:

$\mathrm{GWF}_{\mathrm{I}}=\max \left(\mathrm{GWF}_{\mathrm{N}}, \mathrm{GWF}_{\mathrm{P}}\right)$

where $\mathrm{GWF}_{\mathrm{I}}[\mathrm{mm}]$ is the integrated grey water footprint from considering the $\mathrm{N}$ and $\mathrm{P}$ loads. The total GWF is calculated as the product of GWF and the whole area. The GWS is calculated as:

$\mathrm{GWS}=\mathrm{GWF} / \mathrm{R}$

where $\mathrm{R}$ is the runoff with the same spatiotemporal scale as GWF [mm]. Runoff data are produced by the Distributed Biosphere Hydrological (DBH) model forced by the Princeton global meteorological data (Liu et al., 2016d; Tang et al., 2008). For the management of a water body, assessing the consumption of assimilative capacity caused by pollutants is important (Zhi et al., 2015). With this concept, GWS $<1$ means that the water body still has excess assimilative capacity to accommodate more pollutants; GWS $=1$ means all the assimilative capacity is used up; and GWS $>1$ means that the pollution level has exceeded the assimilative capacity and that the water pollution is thus unsustainable. 
The higher the GWS, the poorer the water quality. In this study, GWS related to $\mathrm{N}(\mathrm{GWS} N), \mathrm{P}\left(\mathrm{GWS}_{\mathrm{P}}\right)$, and their integration $\left(\mathrm{GWS}_{\mathrm{I}}\right)$ are considered.

\subsection{Water quality standards review}

Water standards are the key information required to calculate the GWF and GWS. In different countries, these standards can vary quite substantially. An extensive literature review was conducted on the water standards used for GWF assessments related to $\mathrm{N}$ and $\mathrm{P}$ (Table 1). It reveals some confusion in water quality standards. From the definition of Hoekstra et al. (2011), the ambient environmental water quality standards should be applied in the GWF calculation. However, in the GWF literature to date, the USA and the EU N standards for drinking water, respectively $10 \mathrm{mg} \mathrm{N} \mathrm{L}^{-1}$ and $11.3 \mathrm{mg} \mathrm{N} \mathrm{L}^{-1}$, are the most commonly used water quality standards. Among the 40 reviewed studies (which explicitly used the N-related water quality standards) in Table 1, 30 (75\%) of them used the $\mathrm{N}$ drinking water quality standards. So far, no study has specifically addressed this issue. Some local standards have also been used for regional GWF assessments. It is noted that studies even adopted different standards in the same region/country. For example, in China, three standards for nitrogen were used, i.e. 1 (e.g., Wu et al., 2016), 10 (e.g., Lu et al., 2016), and 12 (Duan et al., 2016) $\mathrm{mg} \mathrm{N} \mathrm{L}^{-1}$ in the literature. Obviously, these different standards introduced significant disparities in GWF accounting. The confusion is partly related to the fact that for many countries, the information on ambient water quality standards are not available, either because they do not exist (e.g., for most African countries and less developed countries) or because of the lack of access to the data sources (e.g., for most of other countries). For P, a few papers addressed the GWF with standards varying from 0.1 to $4 \mathrm{mg} \mathrm{P} \mathrm{L}^{-1}$ (Table 1).

Table 1 Literature review of standards used for grey water footprint assessment.

\begin{tabular}{|c|c|c|c|c|c|c|}
\hline \multirow[b]{2}{*}{ Num. } & \multirow[b]{2}{*}{ Study area } & \multirow{2}{*}{$\begin{array}{c}\text { Nitrogen } \\
\mathrm{C}_{\max } \\
\left(\mathrm{mg} \mathrm{N} \mathrm{L}^{-1}\right)\end{array}$} & \multicolumn{3}{|c|}{ Phosphorus } & \multirow[b]{2}{*}{ References } \\
\hline & & & $\begin{array}{c}\mathrm{C}_{\text {nat }} \\
\left(\mathrm{mg} \mathrm{N} \mathrm{L}^{-1}\right)\end{array}$ & $\begin{array}{c}\mathrm{C}_{\max } \\
\left(\mathrm{mg} \mathrm{P} \mathrm{L}^{-1}\right)\end{array}$ & $\begin{array}{c}\mathrm{C}_{\text {nat }} \\
\left(\mathrm{mg} \mathrm{P} \mathrm{L}^{-1}\right)\end{array}$ & \\
\hline 1 & Argentina $^{\mathrm{R}}$ & 10 (USA) $^{*}$ & -- & -- & -- & (Rodriguez et al., 2015) \\
\hline 2 & Brazil $^{\mathrm{G}+\mathrm{W}}$ & -- & -- & 0.1 (Brazil) & 0 & $\begin{array}{l}\text { (Miguel Ayala et al., } \\
\text { 2016) }\end{array}$ \\
\hline 3 & Brazil $^{\mathrm{R}}$ & 10 (Brazil) $^{*}$ & 0.8 & -- & -- & (Scarpare et al., 2016) \\
\hline 4 & China $^{\mathrm{R}}$ & 12 (China) $^{*}$ & -- & -- & -- & (Duan et al., 2016) \\
\hline 5 & China $^{\mathrm{W}}$ & 1 (China $)^{\#}$ & 0 & & & (Liu et al., 2016a) \\
\hline 6 & China $^{\mathrm{R}}$ & $10(\mathrm{USA})^{*}$ & -- & -- & -- & (Huang et al., 2012) \\
\hline 7 & China $^{\mathrm{R}}$ & 10 (China) $^{*}$ & 0 & -- & -- & (Lu et al., 2016) \\
\hline 8 & China $^{\mathrm{R}}$ & 1 (China) $)^{\#}$ & -- & 0.2 (China) & -- & (Wang et al., 2013) \\
\hline
\end{tabular}




\begin{tabular}{|c|c|c|c|c|c|c|}
\hline 9 & China $^{\mathrm{R}}$ & 1 (China) $)^{\#}$ & 0 & 0.2 (China) & 0 & (Wu et al., 2016) \\
\hline 10 & China $^{\mathrm{R}}$ & 10 (USA) $^{*}$ & -- & -- & -- & (Xu et al., 2015) \\
\hline 11 & China $^{\mathrm{W}}$ & 10 (China) $^{*}$ & 0 & -- & -- & (Zeng et al., 2013) \\
\hline 12 & China $^{\mathrm{G}+\mathrm{R}}$ & 1 (China) $)^{\#}$ & 0.2 & 0.2 (China) & 0.02 & (Zhuo et al., 2016) \\
\hline 13 & England $^{\mathrm{R}}$ & $\begin{array}{l}12.86 \text { (England } \\
\text { and Wales) }\end{array}$ & 6.38 & $\begin{array}{l}0.25 \text { (England } \\
\text { and Wales) }\end{array}$ & 0.01 & (Zhang et al., 2014) \\
\hline 14 & Europe $^{\mathrm{G}+\mathrm{R}}$ & $\begin{array}{l}3.1 \text { (Liu et al., } \\
2012 \text { ) }\end{array}$ & 1.5 & $\begin{array}{l}0.95 \text { (Liu et al., } \\
2012 \text { ) }\end{array}$ & 0.52 & (Mekonnen et al., 2016) \\
\hline 15 & Europe $^{\mathrm{R}}$ & 10 (USA) $^{*}$ & -- & -- & -- & (Thaler et al., 2012) \\
\hline 16 & Europe $^{\mathrm{W}}$ & 10 (USA) $^{*}$ & 0 & -- & -- & $\begin{array}{l}\text { (Vanham and Bidoglio, } \\
\text { 2014) }\end{array}$ \\
\hline 17 & France $^{\mathrm{G}+\mathrm{R}}$ & 10 (USA) $^{*}$ & -- & -- & -- & (Ercin et al., 2013) \\
\hline 18 & Global $^{\mathrm{R}}$ & 10 (USA) $^{*}$ & 0 & -- & -- & (Chapagain et al., 2006) \\
\hline 19 & Global $^{\mathrm{R}}$ & $11.3(\mathrm{EU})^{*}$ & -- & -- & -- & $\begin{array}{l}\text { (Chapagain and Hoekstra, } \\
\text { 2011) }\end{array}$ \\
\hline 20 & Global $^{\mathrm{G}+\mathrm{R}}$ & $10(\mathrm{USA})^{*}$ & 0 & -- & -- & $\begin{array}{l}\text { (Hoekstra and Mekonnen, } \\
\text { 2012) }\end{array}$ \\
\hline 21 & Global $^{\mathrm{W}}$ & 3.1 (Estimated) & 1.5 & 0.95 (Estimated) & 0.52 & (Liu et al., 2012) \\
\hline 22 & Global $^{\mathrm{G}+\mathrm{W}}$ & 2.9 (Canada $)^{\#}$ & 0.4 & -- & -- & $\begin{array}{l}\text { (Mekonnen and Hoekstra, } \\
\text { 2015) }\end{array}$ \\
\hline 23 & Global $^{\mathrm{G}+\mathrm{R}}$ & 10 (USA) $^{*}$ & 0 & -- & -- & $\begin{array}{l}\text { (Mekonnen and Hoekstra, } \\
\text { 2010) }\end{array}$ \\
\hline 24 & Global $^{\mathrm{G}+\mathrm{R}}$ & 10 (USA) $^{*}$ & 0 & -- & -- & $\begin{array}{l}\text { (Mekonnen and Hoekstra, } \\
\text { 2011) }\end{array}$ \\
\hline 25 & Global $^{\mathrm{G}+\mathrm{R}}$ & $10(\mathrm{USA})^{*}$ & 0 & -- & -- & $\begin{array}{l}\text { (Mekonnen and Hoekstra, } \\
\text { 2014) }\end{array}$ \\
\hline 26 & Indonesia ${ }^{\mathrm{R}}$ & 10 (USA) $^{*}$ & -- & -- & -- & (Bulsink et al., 2010) \\
\hline 27 & Italy $^{\mathrm{G}+\mathrm{R}}$ & 10 (USA) $^{*}$ & 0 & -- & -- & $\begin{array}{l}\text { (Aldaya and Hoekstra, } \\
\text { 2010) }\end{array}$ \\
\hline 28 & Italy $^{\mathrm{R}}$ & 15 (Italy) & 0 & -- & -- & (Pellegrini et al., 2016) \\
\hline 29 & Kenya $^{\mathrm{G}+\mathrm{W}}$ & 10 (USA)* & 0 & & & (Mekonnen et al., 2012) \\
\hline 30 & $\begin{array}{l}\text { Latin America } \\
\text { and the } \\
\text { Caribbean }^{\mathrm{G}+\mathrm{R}}\end{array}$ & 10 (USA) $^{*}$ & -- & -- & -- & (Mekonnen et al., 2015) \\
\hline 31 & New Zealand ${ }^{\mathrm{R}}$ & $\begin{array}{l}11.3 \text { (New } \\
\text { Zealand) }\end{array}$ & $0-1.3$ & & & (Deurer et al., 2011) \\
\hline 32 & New Zealand ${ }^{\mathrm{R}}$ & $\begin{array}{l}11.3(\mathrm{New} \\
\text { Zealand) }\end{array}$ & 0 & -- & -- & (Herath et al., 2013) \\
\hline 33 & Morocco $^{\mathrm{R}}$ & 10 (USA)* & -- & -- & -- & $\begin{array}{l}\text { (Schyns and Hoekstra, } \\
\text { 2014) }\end{array}$ \\
\hline 34 & Romania $^{\mathrm{R}}$ & 10 (USA)* & -- & -- & -- & (Ene et al., 2013) \\
\hline 35 & South Africa ${ }^{\mathrm{R}}$ & $\begin{array}{l}4 \text { (South } \\
\text { Africa) }\end{array}$ & 0.62 & $\begin{array}{l}0.13 \text { (South } \\
\text { Africa) }\end{array}$ & 0.06 & (Dabrowski et al., 2009) \\
\hline 36 & South Korea ${ }^{\mathrm{R}}$ & $\begin{array}{l}40 \text { (South } \\
\text { Korea) }\end{array}$ & -- & 4 (South Korea) & -- & (Yoo et al., 2014) \\
\hline 37 & Spain $^{R}$ & $11.3(\mathrm{EU})^{*}$ & -- & -- & -- & Cazcarro et al., 2016) \\
\hline 38 & Spain $^{R}$ & $11.3(\mathrm{EU})^{*}$ & -- & -- & -- & $\begin{array}{l}\text { (Chapagain and Orr, } \\
\text { 2009) }\end{array}$ \\
\hline 39 & Spain $^{W}$ & $11.3(\mathrm{EU})^{*}$ & -- & -- & -- & (Chico et al., 2013) \\
\hline 40 & Spain $^{R}$ & $5.6{\text { (Spain })^{\#}}^{\#}$ & -- & 0.13 (Spain) & -- & $\begin{array}{l}\text { (Pellicer-Martinez and } \\
\text { Martinez-Paz, 2016) }\end{array}$ \\
\hline 41 & 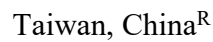 & 10 (Taiwan) $^{*}$ & 0 & -- & -- & (Su et al., 2015) \\
\hline 42 & Tunisia $^{\mathrm{R}}$ & 10 (USA) $^{*}$ & 0 & -- & -- & (Chouchane et al., 2015) \\
\hline 43 & $\mathrm{USA}^{\mathrm{R}}$ & 10 (USA)* & 0 & -- & -- & (Manzardo et al., 2016b) \\
\hline
\end{tabular}

Several national $\mathrm{N}$ and $\mathrm{P}$ standards for drinking water and ambient surface water were

reviewed (Table 2). They show that the allowed $\mathrm{N}$ concentrations for surface water are generally lower

than that for drinking water. This means that the estimated GWF tends to be underestimated by

adopting drinking water standards, which was the case for many previous studies (as shown in Table 
1). As $\mathrm{P}$ is not directly toxic for humans, drinking water standards have not been set for this pollutant.

Some points to note are that in some cases the national $\mathrm{N}$ and $\mathrm{P}$ standards are not unique values but region specific. For example, the USA was divided into 13 ecoregions and there is one standard for each ecoregion (https://www.epa.gov/nutrient-policy-data/ecoregional-criteria). This situation also holds for the Netherlands (Table 2). The way to determine surface water $\mathrm{N}$ standards also varies. For example, the $\mathrm{N}$ surface standard in Canada $\left(3 \mathrm{mg} \mathrm{N} \mathrm{L}^{-1}\right)$ was derived from toxicity tests of aquatic species exposed to environments with different levels of nitrate (http://ceqgrcqe.ccme.ca/download/en/197?redir=1465564929). In the USA, however, it was determined by the 25th of measured nitrate concentrations from surface water (https://www.epa.gov/nutrient-policydata/ecoregional-criteria).

After careful assessment and discussions with experts in ecosystem sciences, the $\mathrm{N}$ standard adopted in this study for surface water is $3 \mathrm{mg} \mathrm{N} \mathrm{L}^{-1}$. This standard is also recommended by Franke et al. (2013). For comparison, the most commonly used $\mathrm{N}$ standard for drinking water $\left(10 \mathrm{mg} \mathrm{N} \mathrm{L}^{-1}\right)$ was also used for GWF calculation related to N. For P, the standard used here is $0.15 \mathrm{mg} \mathrm{P} \mathrm{L}^{-1}$. This standard is recommended by Germany and the EU (Table 2). Many previous studies assumed the natural pollutant concentration to be 0 due to a lack of data (e.g., Chapagain et al., 2006; Liu et al., 2016a; Zeng et al., 2013). However, the natural concentrations of $\mathrm{N}$ and $\mathrm{P}$ are generally higher than 0 , thus such an assumption leads to an underestimation of GWF. In this study, the natural concentration was set to be $0.4 \mathrm{mg} \mathrm{N} \mathrm{L}^{-1}$ and $0.01 \mathrm{mg} \mathrm{P} \mathrm{L}^{-1}$ for $\mathrm{N}$ and $\mathrm{P}$, respectively. The natural concentration for $\mathrm{N}$ of $0.4 \mathrm{mg} \mathrm{N} \mathrm{L}^{-1}$ is recommended by Hoekstra et al. (2011) and Franke et al. (2013), and is also used by Mekonnen and Hoekstra (2015). As for the natural concentration of $\mathrm{P}, 0.01 \mathrm{mg} \mathrm{P} \mathrm{L}^{-1}$, is recommended by Franke et al. (2013). The natural concentration was also considered to be 0 for illustrating the impacts of using different natural concentrations.

Table 2 National water standards for nitrogen $(\mathrm{N})$ and phosphorus $(\mathrm{P})$.

\begin{tabular}{|c|c|c|c|}
\hline & \multicolumn{2}{|c|}{$\mathrm{N}\left(\mathrm{mg} \mathrm{N} \mathrm{L}{ }^{-1}\right)$} & \multirow{2}{*}{$\mathrm{TP}\left(\mathrm{mg} \mathrm{P} \mathrm{L}{ }^{-1}\right)$} \\
\hline & Drinking water & Surface water & \\
\hline Canada & $10\left(\mathrm{NO}_{3}-\mathrm{N}\right)^{\mathrm{R} 1}$ & $3\left(\mathrm{NO}_{3}-\mathrm{N}\right)^{\mathrm{R} 2}$ & $0.02^{\mathrm{R} 3}$ \\
\hline China & $10\left(\mathrm{NO}_{3}-\mathrm{N}\right)^{\mathrm{R} 4}$ & $1(\mathrm{TN}, \text { lakes })^{\mathrm{R} 5}$ & $\begin{array}{l}0.05 \text { (lakes) }^{\mathrm{R} 5} \\
0.2 \text { (rivers) }^{\mathrm{R} 5}\end{array}$ \\
\hline EU & $11.3\left(\mathrm{NO}_{3}-\mathrm{N}\right)^{\mathrm{R} 6}$ & $5.6\left(\mathrm{NO}_{3}-\mathrm{N}\right)^{\mathrm{R} 7}$ & $0.07-0.15^{\mathrm{R} 8}$ \\
\hline Germany & $11.3\left(\mathrm{NO}_{3}-\mathrm{N}\right)^{\mathrm{R} 9}$ & $3(\mathrm{TN})^{\mathrm{R} 10}$ & $0.15^{\mathrm{R} 11}$ \\
\hline
\end{tabular}




\begin{tabular}{|c|c|c|c|}
\hline & & $2.5\left(\mathrm{NO}_{3}-\mathrm{N}\right)^{\mathrm{R} 10}$ & \\
\hline Switzerland & $5.6\left(\mathrm{NO}_{3}-\mathrm{N}\right)^{\mathrm{R} 12}$ & $\begin{array}{l}7(\mathrm{TN})^{\mathrm{R} 13} \\
5.6\left(\mathrm{NO}_{3}-\mathrm{N}\right)^{\mathrm{R} 13}\end{array}$ & $0.07^{\mathrm{R} 13}$ \\
\hline The Netherlands & $11.3\left(\mathrm{NO}_{3}-\mathrm{N}\right)^{\mathrm{R} 14}$ & $0.12-18.05(\mathrm{TN})^{*}, \mathrm{R} 15$ & $0.01-2.5^{*}, \mathrm{R} 15$ \\
\hline USA & $10\left(\mathrm{NO}_{3}-\mathrm{N}\right)^{\mathrm{R} 16}$ & $\begin{array}{l}0.1-1.27(\mathrm{TN}, \text { lakes })^{\mathrm{R} 17} \\
0.12-2.18(\mathrm{TN}, \text { rivers })^{\mathrm{R} 17}\end{array}$ & $\begin{array}{l}0.008-0.038 \text { (lakes) }^{\mathrm{R} 17} \\
0.01-0.076 \text { (rivers) }^{\mathrm{R} 17}\end{array}$ \\
\hline
\end{tabular}
500 water bodies.

R1: http://www.hc-sc.gc.ca/ewh-semt/pubs/water-eau/sum guide-res recom/index-eng.php;

R2: http://ceqg-rcqe.ccme.ca/download/en/197?redir=1465564929;

R3: http://ceqg-rcqe.ccme.ca/download/en/205?redir=1465564939;

R4: http://www.moh.gov.cn/zwgkzt/pgw/201212/33644.shtml;

R5: http://kjs.mep.gov.cn/hjbhbz/bzwb/shjbh/shjzlbz/200206/t20020601 66497.shtml;

R6: http://eur-lex.europa.eu/LexUriServ/LexUriServ.do?uri=OJ:L:1998:330:0032:0054:EN:PDF;

R7: http://eur-lex.europa.eu/legal-content/EN/TXT/PDF/?uri=CELEX:31991L0676\&from=en;

R8: http://eur-lex.europa.eu/LexUriServ/LexUriServ.do?uri=OJ:L:2006:264:0020:0031:EN:PDF;

R9: http://www.gesetze-im-internet.de/bundesrecht/trinkwv 2001/gesamt.pdf;

R10: http://www.vsr-gewaesserschutz.de/33.html;

R11: http://www.vsr-gewaesserschutz.de/20.html;

R12: https://www.admin.ch/opc/en/classified-compilation/19983281/index.html\#app4;

R13: http://www.modul-stufen-konzept.ch/download/ChemieD Juni2010.pdf;

R14: http://wetten.overheid.nl/BWBR0027061/2016-01-01/0/\#BijlageIII;

R15: http://www.helpdeskwater.nl/onderwerpen/wetgeving-beleid/kaderrichtlijn-water/2016-2021/;

R16: https://www.epa.gov/wqc/national-recommended-water-quality-criteria-human-health-criteria-table;

R17: https://www.epa.gov/nutrient-policy-data/ecoregional-criteria.

\section{Results}

\subsection{Grey water footprint assessment}

Global GWF for maize cultivation using $3 \mathrm{mg} \mathrm{N} \mathrm{L}^{-1}$ and $0.15 \mathrm{mg} \mathrm{P} \mathrm{L}^{-1}$ as standards with the natural concentrations of $0.4 \mathrm{mg} \mathrm{N} \mathrm{L}^{-1}$ and $0.01 \mathrm{mg} \mathrm{P} \mathrm{L}^{-1}$ is presented in Fig. 1. It can be seen that $G_{W F}$ is much higher than $G_{W F}$ in many regions. The $G_{W F}$ and $G W F_{P}$ also present different spatial patterns. The North China Plain, northeastern parts of China, and north central parts of the USA are the major regions with a high level of $\operatorname{GWF}_{\mathrm{N}}(>500 \mathrm{~mm})$ (Fig. 1a). While for $\mathrm{GWF}_{\mathrm{P}}$, not only the above mentioned regions, but also southwest parts of China, southern Mexico, and southern Brazil, as well as some parts of central Europe show a high level of GWFP (Fig. 1b). GWF presents quite a similar pattern to $\mathrm{GWF}_{\mathrm{P}}$ (Fig. 1c), implying that $\mathrm{GWF}_{\mathrm{I}}$ is more related to $\mathrm{GWF}_{\mathrm{P}}$ for maize cultivation.

Fig. 1 about here.

The global total $\mathrm{GWF}_{\mathrm{N}}$ for maize is $706 \mathrm{~km}^{3}$ using the drinking water standard $\left(10 \mathrm{mg} \mathrm{N} \mathrm{L}^{-1}\right)$ and increases to $2607 \mathrm{~km}^{3}$ using the ambient water standard $\left(3 \mathrm{mg} \mathrm{N} \mathrm{L}^{-1}\right)$ (Table 3). The conversion of GWF between different standards is straightforward. For example, the $\mathrm{GWF}_{\mathrm{N}}$ with the ambient water quality standard can be obtained by multiplying 3.69 , i.e. the ratio of $(10-0.4)$ to $(3-0.4)$, by the 
$\mathrm{GWF}_{\mathrm{N}}$ calculated using the drinking water quality standard. The global $\mathrm{GWF}_{\mathrm{P}}$ is about 2.7 times that of $\mathrm{GWF}_{\mathrm{N}}$. Although globally $\mathrm{N}$ loads are generally higher than P loads, the higher GWFP is mainly due to the much lower value of maximum allowable concentration for $\mathrm{P}$ than for $\mathrm{N}$. The $\mathrm{GWF}_{\mathrm{I}}$ is only a little higher than $\mathrm{GWF}_{\mathrm{P}}(4 \%)$. This indicates that GWF relating to maize production is mainly determined by P. Asia and North America contribute the largest proportion of global GWF both for N and P, while South America also contributes a high proportion of global GWF . At the country level, China and the USA account for the highest proportion of $\mathrm{GWF}_{\mathrm{N}}$, while the USA, China, and Brazil contribute the most GWF. For the top ten watersheds, the Mississippi plays the dominant role in contributing to $\mathrm{GWF}_{\mathrm{N}}$, while the Mississippi and La Plata show similar roles for GWFp. Disparities of GWF at continental, country, and river basin levels are noticeable. For example, the GWFP (P0.15_0.01, with $0.15 \mathrm{mg} \mathrm{P} \mathrm{L}^{-1}$ and $0.01 \mathrm{mg} \mathrm{P} \mathrm{L}^{-1}$ as standard and natural concentration) is about 2.2 times that of $\mathrm{GWF}_{\mathrm{N}}\left(\mathrm{N}_{3}{ }_{0} 0.4\right.$, with $3 \mathrm{mg} \mathrm{N} \mathrm{L}^{-1}$ and $0.4 \mathrm{mg} \mathrm{N} \mathrm{L}^{-1}$ as standard and natural concentration) in Asia, however it decreases to 1.4 times in China and only accounts for $55 \%$ of the $\mathrm{GWF}_{\mathrm{N}}$ of the Haihe river basin. 

in maize production at different geographical levels $\left(\mathrm{km}^{3}\right)$.

\begin{tabular}{|c|c|c|c|c|}
\hline \multicolumn{5}{|c|}{ Continental level } \\
\hline & N10_0.4 ${ }^{\mathrm{a}}$ & N3_0. $4^{\mathrm{b}}$ & P0.15_0.01 ${ }^{\mathrm{c}}$ & $\mathrm{GWF}_{\mathrm{I}}^{\mathrm{d}}$ \\
\hline Africa & 33.5 & 123.7 & 563.2 & 586.9 \\
\hline Asia & 284.1 & 1049.1 & 2297.2 & 2459.0 \\
\hline Europe & 75.1 & 277.2 & 666.9 & 681.0 \\
\hline N. America & 236.1 & 871.9 & 2056.5 & 2102.7 \\
\hline Oceania & 0.3 & 1.0 & 6.6 & 6.6 \\
\hline S. America & 76.8 & 283.6 & 1395.1 & 1397.5 \\
\hline Global & 706.0 & 2606.7 & 6985.5 & 7233.7 \\
\hline \multicolumn{5}{|c|}{ Top 10 maize-producing countries* } \\
\hline & $\mathrm{N} 10 \_0.4^{\mathrm{a}}$ & N3_0.4 ${ }^{\mathrm{b}}$ & P0.15_0.01 ${ }^{\mathrm{c}}$ & $\mathrm{GWF}^{\mathrm{d}}$ \\
\hline USA & 160.4 & 592.4 & 1233.4 & 1275.3 \\
\hline China & 208.5 & 769.9 & 1097.3 & 1252.2 \\
\hline Brazil & 54.9 & 202.6 & 1088.2 & 1089.2 \\
\hline Mexico & 46.9 & 173.3 & 547.4 & 548.5 \\
\hline India & 18.2 & 67.2 & 365.7 & 365.7 \\
\hline Russia & 2.8 & 10.4 & 64.0 & 64.1 \\
\hline Nigeria & 4.1 & 15.0 & 116.5 & 116.6 \\
\hline Argentina & 8.2 & 30.4 & 125.6 & 125.6 \\
\hline Ukraine & 1.8 & 6.6 & 35.5 & 35.5 \\
\hline France & 25.6 & 94.5 & 123.3 & 131.8 \\
\hline \multicolumn{5}{|c|}{ Top 10 maize-producing watersheds* } \\
\hline & N10_0.4 ${ }^{\mathrm{a}}$ & N3_0.4 & P0.15_0.01 ${ }^{\mathrm{c}}$ & $\mathrm{GWF}^{\mathrm{d}}$ \\
\hline Mississippi & 132.6 & 489.8 & 988.0 & 1023.9 \\
\hline La Plata & 44.6 & 164.5 & 843.2 & 843.2 \\
\hline Danube & 11.5 & 42.3 & 144.0 & 144.7 \\
\hline Amur & 37.1 & 137.0 & 113.4 & 158.4 \\
\hline Haihe & 35.2 & 129.8 & 71.4 & 136.1 \\
\hline Yangtze & 37.7 & 139.3 & 368.3 & 368.6 \\
\hline St Lawrence & 21.4 & 79.1 & 148.1 & 149.7 \\
\hline China Coast & 47.3 & 174.7 & 281.4 & 287.6 \\
\hline $\begin{array}{l}\text { Ganges- } \\
\text { Bramaputra }\end{array}$ & 12.0 & 44.3 & 248.0 & 248.0 \\
\hline Yellow & 22.8 & 84.3 & 63.6 & 91.4 \\
\hline
\end{tabular}

*The top 10 maize-producing countries and top 10 maize-producing watersheds are based on the maize cultivated areas; a: $\mathrm{GWF}_{\mathrm{N}}$ with $10 \mathrm{mg} \mathrm{N} \mathrm{L}^{-1}$ and $0.4 \mathrm{mg} \mathrm{N} \mathrm{L}^{-1}$ as standard and natural concentration; b: GWF with $3 \mathrm{mg} \mathrm{N} \mathrm{L}^{-1}$ and $0.4 \mathrm{mg} \mathrm{N}$ $\mathrm{L}^{-1}$ as standard and natural concentration; c: GWFP with $0.15 \mathrm{mg} \mathrm{P} \mathrm{L}^{-1}$ and $0.01 \mathrm{mg} \mathrm{P} \mathrm{L}^{-1}$ as standard and natural concentration; $\mathrm{d}$ : $\mathrm{GWF}_{\mathrm{I}}$ with $3 \mathrm{mg} \mathrm{N} \mathrm{L}^{-1}$ and $0.15 \mathrm{mg} \mathrm{P} \mathrm{L}^{-1}$ as the standards, and $0.4 \mathrm{mg} \mathrm{N} \mathrm{L}^{-1}$ and $0.01 \mathrm{mg} \mathrm{P} \mathrm{L}^{-1}$ as natural concentrations for nitrogen and phosphorus.

\subsection{Grey water stress assessment} regions, GWS is generally higher than 1. For example, the $\mathrm{GWS}_{\mathrm{N}}$ is higher than 1 in the northeastern parts of China and northeastern parts of the USA (Fig. 2a). The high GWS in these regions implies 
that the assimilative capacity of the local water resource has been fully consumed and that a process of water environmental degradation is ongoing. In contrast, the GWS presents an optimistic view at the watershed level, as the average values computed for a watershed may hide the extreme values of GWS at a grid level. Most river basins present GWS lower than 0.3, except $\mathrm{GWF}_{\mathrm{N}}$ and $\mathrm{GWS}_{\mathrm{I}}$ in the Haihe river basin of China.

Fig. 2 about here.

To demonstrate the disparities of GWS due to different water quality standards and natural concentrations, different pollutants, and the integration of different pollutants, the fractions of grid number with GWS $>1$ in the total grid number for maize cultivation under different conditions were compared (Fig. 3). The fraction for $\mathrm{GWS}_{\mathrm{N}}$ using the ambient water quality standard $\left(3 \mathrm{mg} \mathrm{N} \mathrm{L}^{-1}\right)$ is much higher (about 5 times) than that using the drinking water quality standard $\left(10 \mathrm{mg} \mathrm{N} \mathrm{L}^{-1}\right)$, although the difference in water quality standards is only 3.3 times. Different natural concentrations also contribute to the disparities for both $\mathrm{GWS}_{\mathrm{N}}$ and $\mathrm{GWS}_{\mathrm{P}}$. The fractions derived from P loads are much higher than those derived from $\mathrm{N}$ loads. For example, the fraction is about $2.5 \%$ for $\mathrm{GWS}_{\mathrm{N}}$ with $3 \mathrm{mg} \mathrm{N} \mathrm{L}^{-1}$ and $0.4 \mathrm{mg} \mathrm{N} \mathrm{L}^{-1}$ as standard and natural concentration, while it increases to $5.1 \%$ for $\mathrm{GWS}_{\mathrm{P}}$ with $0.15 \mathrm{mg} \mathrm{P} \mathrm{L}^{-1}$ and $0.4 \mathrm{mg} \mathrm{P} \mathrm{L}^{-1}$ as standard and natural concentration. When considering the integration of $\mathrm{N}$ and $\mathrm{P}$, about $5.8 \%$ of total maize cultivation grids show GWS $>1$.

Fig. 3 about here.

\section{Discussion}

The key point addressed in this study is that there are multi-dimensional disparities of GWF assessments that prevent the indicator from providing a consistent value for water quality and being a tool for sound policy supporting in the water sector. It is here argued that improving the robustness of GWF assessments is necessary to gain a more comprehensive understanding of the impacts of human activities on water quality. To the best of our knowledge, this study is the first attempt to comprehensively address the main shortcomings of GWF accounting and to propose ways of improving it. 
First, the influence of water quality standards and natural concentration levels on GWF assessment

was addressed. The GWF is generally estimated using water quality standards for the receiving freshwater bodies, which can be formulated at the national (e.g., for Switzerland) or regional level (e.g., the EU Water Framework Directive). However, as these standards do not exist for all pollutants and for all countries, it is difficult to make consistent analyses in some circumstances. The choice of whether to use environmental or drinking water quality standards in GWF assessments is also a matter of great importance (Table 3). It is highly recommended that the standards used are verified when performing a comparison with results from different studies. Ambient water quality standards also vary considerably from one substance to another and from one country or region to another. This point needs to be addressed, as the choice of inputs and parameter values determines the major disparities in GWF assessments, as also highlighted by Mekonnen and Hoekstra (2015).

It should be highlighted here that for $\mathrm{N}$, ambient water standards are consistently higher than drinking water standards (Table 2). A number of water scientists from the Swiss Federal Institute for Aquatic Science and Technology (Eawag) have been consulted and a review of the relevant literature for the explanation of these differences has been conducted. It has emerged that fish, shellfish, and smaller organisms that live in water are more sensitive to $\mathrm{N}$ than humans are. Their small bodies make them less tolerant to the concentration of the pollutants. Therefore, the use of drinking water standards underestimates GWF (Table 2). The P pollution in freshwater bodies is not directly toxic to humans and animals. This is the main reason that there is generally no drinking water standard for P. It has, however, an indirect toxicity as it causes proliferation of toxic algal blooms and results in the depletion of oxygen, which kills fish (Carpenter et al., 1998). Nitrate loads into water, in contrast, pose a direct threat for the health of humans and other mammals. High concentration of nitrate has been linked to cancers and methemoglobinemia in infants, as well as to toxic effects on livestock (e.g., abortions in cattle).

The assumptions on natural concentration also largely influence the results of GWF analyses. As shown by Liu et al. (2012), changes in natural concentration levels can result in large disparities in GWS assessment. It is also noteworthy to say that it is not easy to account for natural concentration in 
a receiving body. Some studies have assumed the natural concentration to be zero. In reality, this cannot be the case, as nutrients are transported through river systems and interact with sediments. As different ecosystems respond differently to nutrient loads, to produce meaningful results, GWF assessments should be based on basin-specific values for both maximum allowable concentration and natural concentration for different nutrients. Experimental studies are needed to support more robust GWF assessments.

The second point raised in the present study is that the co-existence of multiple pollutants in water bodies (e.g. N and P, pesticides, herbicides, heavy metals, and other harmful chemical compounds) needs to be considered in GWF assessments. The majority of GWF assessments only considers anthropogenic N loads to water (e.g., Hoekstra and Mekonnen, 2012; Mekonnen and Hoekstra, 2015; O'Bannon et al., 2014) (Table 1), while neglecting the existence of other pollutants. In this study, an integrated GWF by considering the highest GWF of individual pollutants was explicitly illustrated using $\mathrm{N}$ and $\mathrm{P}$ losses in global maize cultivation as example. The result demonstrates that it is important to consider P-related loads into water, as the dilution of this input is much more water intensive than the dilution of N-loads. This is because eutrophication in water bodies is more likely caused by P (Schindler et al., 2008). Therefore, the P-related water quality standards are far more stringent than those for N. It can also be argued that, as the pollutant that has the highest GWF is often unknown or cannot be determined in the water body, an aggregated water quality indicator, which takes all possible pollutants into account with a weighting factor, may be more appropriate for GWF accounting. But how to determine such an indicator deserves further investigation.

Third, this study addressed the disparities arising from the use of different spatial scales. The analysis has shown that the good condition of GWS at the basin level hides the potential negative impacts at the grid level. This is because the grid level assessment provides information on local concentration of pollution, whereas the basin level assessment gives the average concentration in the whole basin which can smooth out the high concentration in many local areas. Hence, the river basin level GWF may provide wrong information on the criticality of water pollution situation, impairing sound policy making for water resource management. Though watersheds hold the complete 
hydrological processes, it seems that water pollution intensity should be assessed by treating sources of pollution which are located in different parts of a basin. When the water pollution happens in the upstream of a basin, the situation may be different from if it happens in the down steam. For example, the GWS of $\mathrm{N}$ at Mississippi is only $0.04-0.08$ when taking it as a whole area (Fig. 2). However, a large number of grids in its northeastern parts present GSW larger than 1. It is difficult to use the downstream water resources to deal with the upstream water pollution. Therefore, assessing the GWF and GWS at the grid level should have a higher priority. The grid level was also recommended by Mekonnen and Hoekstra (2014), where they compared the green and blue water footprint at the grid, provincial, and country levels. For this reason, the current study focused on the grid level for evaluating the disparities of GWS as shown in Fig. 3.

Finally, it should be mentioned that this study did not consider accumulation and degradation of the lost $\mathrm{N}$ and $\mathrm{P}$ in the receiving water bodies. Also, the effects of different forms of lost $\mathrm{N}$ and $\mathrm{P}$ on the aquatic ecosystem were not considered. This is because it is difficult to determine exact loads of individual forms in which the lost $\mathrm{N}$ and $\mathrm{P}$ present in water bodies due to the complex chemical and biological processes involved. For this reason, studies in grey water footprint so far have used a certain element as a proxy for $\mathrm{N}$ and $\mathrm{P}$ loads, e.g., total losses to water regardless forms and fates of the pollutant (such as in this study and many other studies, including Hoekstra and Mekonnen (2012) and Mekonnen and Hoekstra (2015)). Only few have used dissolved inorganic N and P, dissolved organic $\mathrm{N}$ and $\mathrm{P}$, and total $\mathrm{N}$ and $\mathrm{P}$ (Liu et al., 2012). It is clear that using different forms of a certain pollution element will lead to different results of GWF. However, a detailed analysis of the fate of the lost N and $\mathrm{P}$ and the involved chemical and biological processes is beyond the scope of this study, but deserves further investigation in the future.

\section{Conclusions}

This study has discussed some major limitations of GWF assessment in the literature and proposed several ways towards its improvement. It provides a first exploration on how the GWF assessment can be enhanced from a methodological point of view, with an illustration for $\mathrm{N}$ and $\mathrm{P}$ loads into water relating to global maize cultivation. The insights provided can be used to investigate GWF from 
multiple crops and pollutants and water quality parameters. The approach taken in this study can also be used to provide a scientifically sound frame of reference for evaluating the trade-offs of importing rather than producing different crops in different locations from both a water quality and water quantity perspective. Finally, improving the scientific soundness of GWF assessments can better inform national and local governments about the pressure on water systems from agrochemical pollutants and serve as a tool for setting water pollution reduction targets based on the consumption of assimilation capacity of water bodies.

\section{Acknowledgements}

The authors would like to thank Dr. Nele Schuwirth, Dr. Kai Ubert, and Dr. Marion Junghans from Eawag, and Dr. Els Smit from the Centre for Safety of Substances and Products, National Institute for Public Health and the Environment of the Netherlands for the scientific support, particularly for clarification of drinking and surface water quality standards and the knowledge underlying these standards. We also thank four anonymous reviewers' constructive comments for improving the quality of the initial manuscript. 


\section{References}

Aldaya, M.M., Hoekstra, A.Y., 2010. The water needed for Italians to eat pasta and pizza. Agr. Syst. 103, 351360.

Bennett, E.M., Carpenter, S.R., Caraco, N.F., 2001. Human impact on erodable phosphorus and eutrophication: A global perspective. Bioscience 51, 227-234.

Bulsink, F., Hoekstra, A.Y., Booij, M.J., 2010. The water footprint of Indonesian provinces related to the consumption of crop products. Hydrol. Earth Syst. Sci. 14, 119-128.

Carpenter, S.R., Caraco, N.F., Correll, D.L., Howarth, R.W., Sharpley, A.N., Smith, V.H., 1998. Nonpoint pollution of surface waters with phosphorus and nitrogen. Ecol. Appl. 8, 559-568.

Cazcarro, I., Duarte, R., Sánchez-Chóliz, J., 2016. Downscaling the grey water footprints of production and consumption. J. Clean. Prod. 132, 171-183.

Chapagain, A.K., Hoekstra, A.Y., 2011. The blue, green and grey water footprint of rice from production and consumption perspectives. Ecol. Econ. 70, 749-758.

Chapagain, A.K., Hoekstra, A.Y., Savenije, H.H.G., Gautam, R., 2006. The water footprint of cotton consumption: An assessment of the impact of worldwide consumption of cotton products on the water resources in the cotton producing countries. Ecol. Econ. 60, 186-203.

Chapagain, A.K., Orr, S., 2009. An improved water footprint methodology linking global consumption to local water resources: A case of Spanish tomatoes. J. Environ. Manage. 90, 1219-1228.

Chico, D., Aldaya, M.M., Garrido, A., 2013. A water footprint assessment of a pair of jeans: the influence of agricultural policies on the sustainability of consumer products. J. Clean. Prod. 57, 238-248.

Chouchane, H., Hoekstra, A.Y., Krol, M.S., Mekonnen, M.M., 2015. The water footprint of Tunisia from an economic perspective. Ecol. Indic. 52, 311-319.

Dabrowski, J.M., Murray, K., Ashton, P.J., Leaner, J.J., 2009. Agricultural impacts on water quality and implications for virtual water trading decisions. Ecol. Econ. 68, 1074-1082.

Deurer, M., Green, S.R., Clothier, B.E., Mowat, A., 2011. Can product water footprints indicate the hydrological impact of primary production? - A case study of New Zealand kiwifruit. J. Hydrol. 408, 246-256.

Duan, P., Qin, L., Wang, Y., He, H., 2016. Spatial pattern characteristics of water footprint for maize production in Northeast China. J. Sci. Food Agric. 96, 561-568.

Ene, S.A., Teodosiu, C., Robu, B., Volf, I., 2013. Water footprint assessment in the winemaking industry: a case study for a Romanian medium size production plant. J. Clean. Prod. 43, 122-135. 
Ercin, A.E., Mekonnen, M.M., Hoekstra, A.Y., 2013. Sustainability of national consumption from a water resources perspective: The case study for France. Ecol. Econ. 88, 133-147.

Falkenmark, M., Lindh, G., 1974. How can we cope with the water resources situation by the year 2015? Ambio, $3,114-122$.

Franke, N., Hoekstra, A., Boyacioglu, H., 2013. Grey water footprint accounting: Tier 1 supporting guidelines. Value of Water Research Report Series No. 65, UNESCO-IHE, Delft, Netherlands.

Galloway, J.N., Cowling, E.B., 2002. Reactive nitrogen and the world: 200 years of change. Ambio 31, 64-71.

Galloway, J.N., Townsend, A.R., Erisman, J.W., Bekunda, M., Cai, Z.C., Freney, J.R., Martinelli, L.A., Seitzinger, S.P., Sutton, M.A., 2008. Transformation of the nitrogen cycle: Recent trends, questions, and potential solutions. Science 320, 889-892.

Herath, I., Green, S., Singh, R., Horne, D., van der Zijpp, S., Clothier, B., 2013. Water footprinting of agricultural products: a hydrological assessment for the water footprint of New Zealand's wines. J. Clean. Prod. 41, 232-243.

Hoekstra, A.Y. (Ed), 2003. Virtual water trade: Proceedings of the international expert meeting on virtual water trade. Value of Water Research Report Series No. 12, UNESCO-IHE, Delft, Netherlands.

Hoekstra, A.Y., Chapagain, A.K., 2008. Globalization of water: Sharing the planet's freshwater resources. Earthscan, London.

Hoekstra, A.Y., Chapagain, A.K., Aldaya, M.M., Mekonnen, M.M., 2011. The water footprint assessment manual: Setting the global standard. Earthscan, London.

Hoekstra, A.Y., Mekonnen, M.M., 2012. The water footprint of humanity. P. Natl. Acad. Sci. U.S.A. 109, 32323237.

Huang, J., Zhang, H., Tong, W., Chen, F., 2012. The impact of local crops consumption on the water resources in Beijing. J. Clean. Prod. 21, 45-50.

Lamastra, L., Suciu, N.A., Novelli, E., Trevisan, M., 2014. A new approach to assessing the water footprint of wine: An Italian case study. Sci. Total Environ. 490, 748-756.

Liu, C., Kroeze, C., Hoekstra, A.Y., Gerbens-Leenes, W., 2012. Past and future trends in grey water footprints of anthropogenic nitrogen and phosphorus inputs to major world rivers. Ecol. Indic. 18, 42-49.

Liu, J., Liu, Q., Yang, H., 2016a. Assessing water scarcity by simultaneously considering environmental flow requirements, water quantity, and water quality. Ecol. Indic. 60, 434-441.

Liu, W., Yang, H., Folberth, C., Wang, X., Luo, Q., Schulin, R., 2016b. Global investigation of impacts of PET methods on simulating crop-water relations for maize. Agric. For. Meteorol. 221, 164-175. 
Liu, W., Yang, H., Liu, J., Azevedo, L.B., Wang, X., Xu, Z., Abbaspour, K.C., Schulin, R., 2016c. Global assessment of nitrogen losses and trade-offs with yields from major crop cultivations. Sci. Total Environ. $572,526-537$.

Liu, X., Tang, Q., Zhang, X., Leng, G., 2016d. Modeling the role of vegetation in hydrological responses to climate change, in: Tang, Q. and Oki, T. (Eds.), Terrestrial Water Cycle and Climate Change: Natural and Human-Induced Impacts. Wiley \& Sons Inc., Hoboken, New Jersey, pp. 193-208.

Lu, Y., Zhang, X., Chen, S., Shao, L., Sun, H., 2016. Changes in water use efficiency and water footprint in grain production over the past 35 years: a case study in the North China Plain. J. Clean. Prod. 116, 7179.

Manzardo, A., Loss, A., Fialkiewicz, W., Rauch, W., Scipioni, A., 2016a. Methodological proposal to assess the water footprint accounting of direct water use at an urban level: A case study of the Municipality of Vicenza. Ecol. Indic. 69, 165-175.

Manzardo, A., Mazzi, A., Loss, A., Butler, M., Williamson, A., Scipioni, A., 2016b. Lessons learned from the application of different water footprint approaches to compare different food packaging alternatives. J. Clean. Prod. 112, 4657-4666.

Mekonnen, M.M., Hoekstra, A.Y., 2010. A global and high-resolution assessment of the green, blue and grey water footprint of wheat. Hydrol. Earth Syst. Sci. 14, 1259-1276.

Mekonnen, M.M., Hoekstra, A.Y., 2011. The green, blue and grey water footprint of crops and derived crop products. Hydrol. Earth Syst. Sci. 15, 1577-1600.

Mekonnen, M.M., Hoekstra, A.Y., 2014. Water footprint benchmarks for crop production: A first global assessment. Ecol. Indic. 46, 214-223.

Mekonnen, M.M., Hoekstra, A.Y., 2015. Global gray water footprint and water pollution levels related to anthropogenic nitrogen loads to fresh water. Environ. Sci. Technol. 49, 12860-12868.

Mekonnen, M.M., Hoekstra, A.Y., Becht, R., 2012. Mitigating the water footprint of export cut flowers from the lake Naivasha basin, Kenya. Water Resour. Manage. 26, 3725-3742.

Mekonnen, M.M., Lutter, S., Martinez, A., 2016. Anthropogenic nitrogen and phosphorus emissions and related grey water footprints caused by EU-27's crop production and consumption. Water, 8. doi:10.3390/w8010030

Mekonnen, M.M., Pahlow, M., Aldaya, M.M., Zarate, E., Hoekstra, A.Y., 2015. Sustainability, Efficiency and Equitability of Water Consumption and Pollution in Latin America and the Caribbean. Sustainability 7 , 2086-2112. 
Miguel Ayala, L., van Eupen, M., Zhang, G., Pérez-Soba, M., Martorano, L.G., Lisboa, L.S., Beltrao, N.E., 2016. Impact of agricultural expansion on water Footprint in the Amazon under climate change scenarios. Sci. Total Environ. 569-570, 1159-1173.

Mueller, N.D., Gerber, J.S., Johnston, M., Ray, D.K., Ramankutty, N., Foley, J.A., 2012. Closing yield gaps through nutrient and water management. Nature 490, 254-257.

O'Bannon, C., Carr, J., Seekell, D.A., D'Odorico, P., 2014. Globalization of agricultural pollution due to international trade. Hydrol. Earth Syst. Sci. 18, 503-510.

Obersteiner, M., Penuelas, J., Ciais, P., van der Velde, M., Janssens, I.A., 2013. The phosphorus trilemma. Nat. Geosci. 6, 897-898.

Pellegrini, G., Ingrao, C., Carnposeo, S., Tricase, C., Conto, F., Huisingh, D., 2016. Application of water footprint to olive growing systems in the Apulia region: a comparative assessment. J. Clean. Prod. 112, 2407-2418.

Pellicer-Martinez, F., Martinez-Paz, J.M., 2016. Grey water footprint assessment at the river basin level: Accounting method and case study in the Segura River Basin, Spain. Ecol. Indic. 60, 1173-1183.

Portmann, F.T., Siebert, S., Doll, P., 2010. MIRCA2000-Global monthly irrigated and rainfed crop areas around the year 2000: A new high-resolution data set for agricultural and hydrological modeling. Global Biogeochem. Cy. 24. doi:10.1029/2008GB003435

Rodriguez, C.I., de Galarreta, V.A.R., Kruse, E.E., 2015. Analysis of water footprint of potato production in the pampean region of Argentina. J. Clean. Prod. 90, 91-96.

Scarpare, F.V., Hernandes, T.A.D., Ruiz-Correa, S.T., Kolln, O.T., Gava, G.J.D.C., dos Santos, L.N.S., Victoria, R.L., 2016. Sugarcane water footprint under different management practices in Brazil: Tiete/Jacare watershed assessment. J. Clean. Prod. 112, 4576-4584.

Schindler, D.W., Hecky, R.E., Findlay, D.L., Stainton, M.P., Parker, B.R., Paterson, M.J., Beaty, K.G., Lyng, M., Kasian, S.E.M., 2008. Eutrophication of lakes cannot be controlled by reducing nitrogen input: Results of a 37-year whole-ecosystem experiment. Proc. Natl. Acad. Sci. U.S.A. 105, 11254-11258.

Schyns, J.F., Hoekstra, A.Y., 2014. The Added Value of Water Footprint Assessment for National Water Policy: A Case Study for Morocco. PLoS One 9. doi:10.1371/journal.pone.0099705.

Su, M., Huang, C., Li, W., Tso, C., Lur, H.S., 2015. Water footprint analysis of bioethanol energy crops in Taiwan. J. Clean. Prod. 88, 132-138. 
Suttayakul, P., H-Kittikun, A., Suksaroj, C., Mungkalasiri, J., Wisansuwannakorn, R., Musikavong, C., 2016. Water footprints of products of oil palm plantations and palm oil mills in Thailand. Sci. Total Environ. $542,521-529$.

Sutton, M.A., Bleeker, A., Howard, C., Bekunda, M., Grizzetti, B., Vries, W.d., Van Grinsven, H., Abrol, Y., Adhya, T., Billen, G., 2013. Our Nutrient World: the challenge to produce more food and energy with less pollution. Centre for Ecology and Hydrology (CEH).

Tang, Q., Oki, T., Kanae, S., Hu, H., 2008. Hydrological cycles change in the Yellow River basin during the last half of the twentieth century. J. Climate 21, 1790-1806.

Thaler, S., Zessner, M., De Lis, F.B., Kreuzinger, N., Fehringer, R., 2012. Considerations on methodological challenges for water footprint calculations. Water Sci. Technol. 65, 1258-1264.

Vanham, D., Bidoglio, G., 2014. The water footprint of agricultural products in European river basins. Environ. Res. Lett. 9. doi:10.1088/1748-9326/9/6/064007.

Vitousek, P.M., Aber, J.D., Howarth, R.W., Likens, G.E., Matson, P.A., Schindler, D.W., Schlesinger, W.H., Tilman, D., 1997. Human alteration of the global nitrogen cycle: Sources and consequences. Ecol. Appl. 7, 737-750.

Vitousek, P.M., Naylor, R., Crews, T., David, M.B., Drinkwater, L.E., Holland, E., Johnes, P.J., Katzenberger, J., Martinelli, L.A., Matson, P.A., Nziguheba, G., Ojima, D., Palm, C.A., Robertson, G.P., Sanchez, P.A., Townsend, A.R., Zhang, F.S., 2009. Nutrient imbalances in agricultural development. Science 324, 1519-1520.

Wang, Z., Huang, K., Yang, S., Yu, Y., 2013. An input-output approach to evaluate the water footprint and virtual water trade of Beijing, China. J. Clean. Prod. 42, 172-179.

West, P.C., Gerber, J.S., Engstrom, P.M., Mueller, N.D., Brauman, K.A., Carlson, K.M., Cassidy, E.S., Johnston, M., MacDonald, G.K., Ray, D.K., Siebert, S., 2014. Leverage points for improving global food security and the environment. Science $345,325-328$.

Williams, J.R., 1995. The EPIC model, in: Singh, V.P. (Ed.), Computer Models of Watershed hydrology. Water Resources Publications, Highlands Ranch, Colo, pp. 909-1000.

Williams, J.R., Jones, C.A., Dyke, P.T., 1984. A modeling approach to determining the relationship between erosion and soil productivity. T. Asae 27, 129-144.

Wu, B., Zeng, W., Chen, H., Zhao, Y., 2016. Grey water footprint combined with ecological network analysis for assessing regional water quality metabolism. J. Clean. Prod. 112, 3138-3151. 
Xu, Y., Huang, K., Yu, Y., Wang, X., 2015. Changes in water footprint of crop production in Beijing from 1978 to 2012: a logarithmic mean Divisia index decomposition analysis. J. Clean. Prod. 87, 180-187.

Yoo, S.H., Choi, J.Y., Lee, S.H., Kim, T., 2014. Estimating water footprint of paddy rice in Korea. Paddy Water Environ. 12, 43-54.

Zeng, Z., Liu, J., Savenije, H.H.G., 2013. A simple approach to assess water scarcity integrating water quantity and quality. Ecol. Indic. 34, 441-449.

Zhang, G., Mathews, R.E., Frapporti, G., Mekonnen, M.M., 2014. Water footprint assessment for the Hertfordshire and north London area. Report RESE000335, Environment Agency, London, UK.

Zhi, Y., Yang, Z., Yin, X., Hamilton, P.B., Zhang, L., 2015. Using gray water footprint to verify economic sectors' consumption of assimilative capacity in a river basin: model and a case study in the Haihe River Basin, China. J. Clean. Prod. 92, 267-273.

Zhuo, L., Mekonnen, M.M., Hoekstra, A.Y., Wada, Y., 2016. Inter- and intra-annual variation of water footprint of crops and blue water scarcity in the Yellow River basin (1961-2009). Adv. Water Resour. 87, 29-41. 


\section{Figure captions}

Fig. 1 Grey water footprint $(\mathrm{GWF})$ related to nitrogen $\left(\mathrm{GWF}_{\mathrm{N}}\right)$, phosphorus $(\mathrm{GWF})$, and their integration $\left(\mathrm{GWF}_{\mathrm{I}}\right)$ in maize production by using $3 \mathrm{mg} \mathrm{N} \mathrm{L}^{-1}$ and $0.15 \mathrm{mg} \mathrm{P} \mathrm{L}^{-1}$ as the standards, and $0.4 \mathrm{mg} \mathrm{N} \mathrm{L}^{-1}$ and $0.01 \mathrm{mg} \mathrm{P} \mathrm{L}^{-1}$ as natural concentrations for nitrogen and phosphorus.

(a) $\mathrm{GWF}_{\mathrm{N}}$

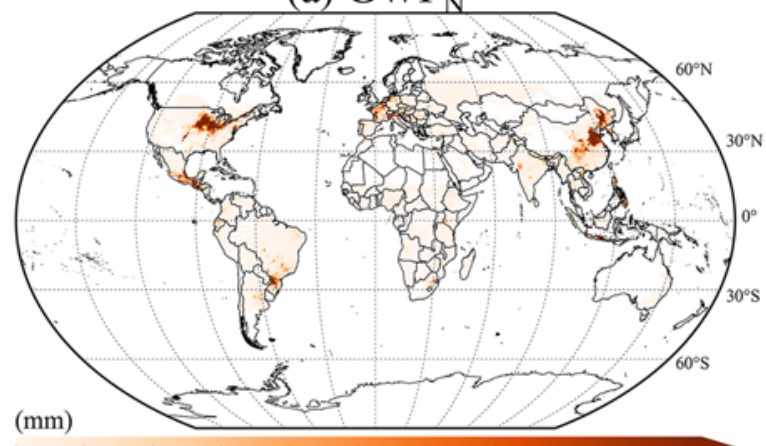

$\begin{array}{lllllllllll}0 & 50 & 100 & 150 & 200 & 250 & 300 & 350 & 400 & 450 & 500\end{array}$

(b) $\mathrm{GWF}_{\mathrm{P}}$

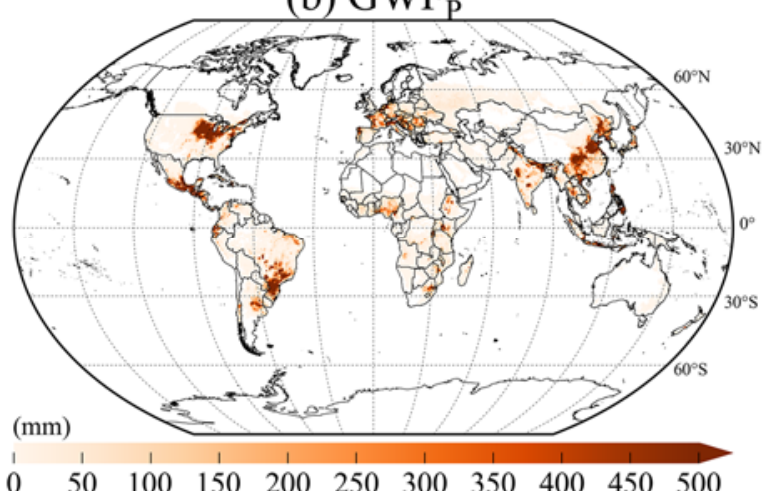

(c) $\mathrm{GWF}_{\mathrm{I}}$

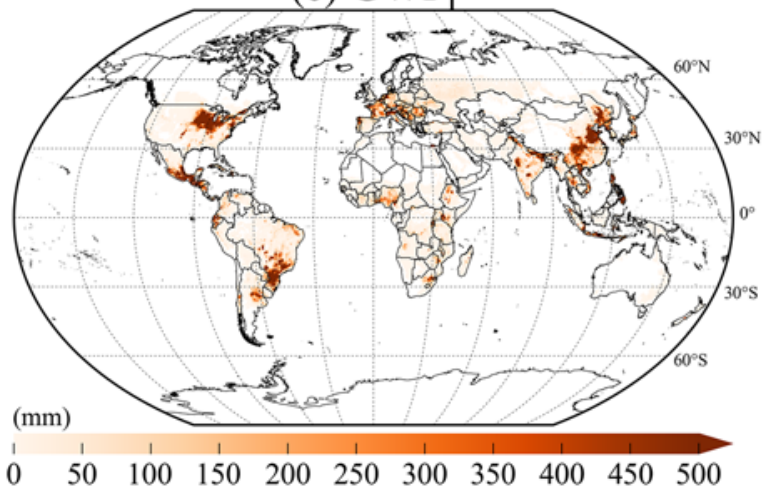


Fig. 2 Grey water stress (GWS) related to nitrogen $\left(G_{W}\right)$, phosphorus (GWSP), and their integration $\left(G^{2} S_{I}\right)$ in maize production at grid and watershed levels by using $3 \mathrm{mg} \mathrm{N} \mathrm{L}^{-1}$ and $0.15 \mathrm{mg} \mathrm{P} \mathrm{L}^{-1}$ as standards, and $0.4 \mathrm{mg} \mathrm{N} \mathrm{L}^{-1}$ and $0.01 \mathrm{mg}$ $\mathrm{P} \mathrm{L}^{-1}$ as natural concentrations for nitrogen and phosphorus.
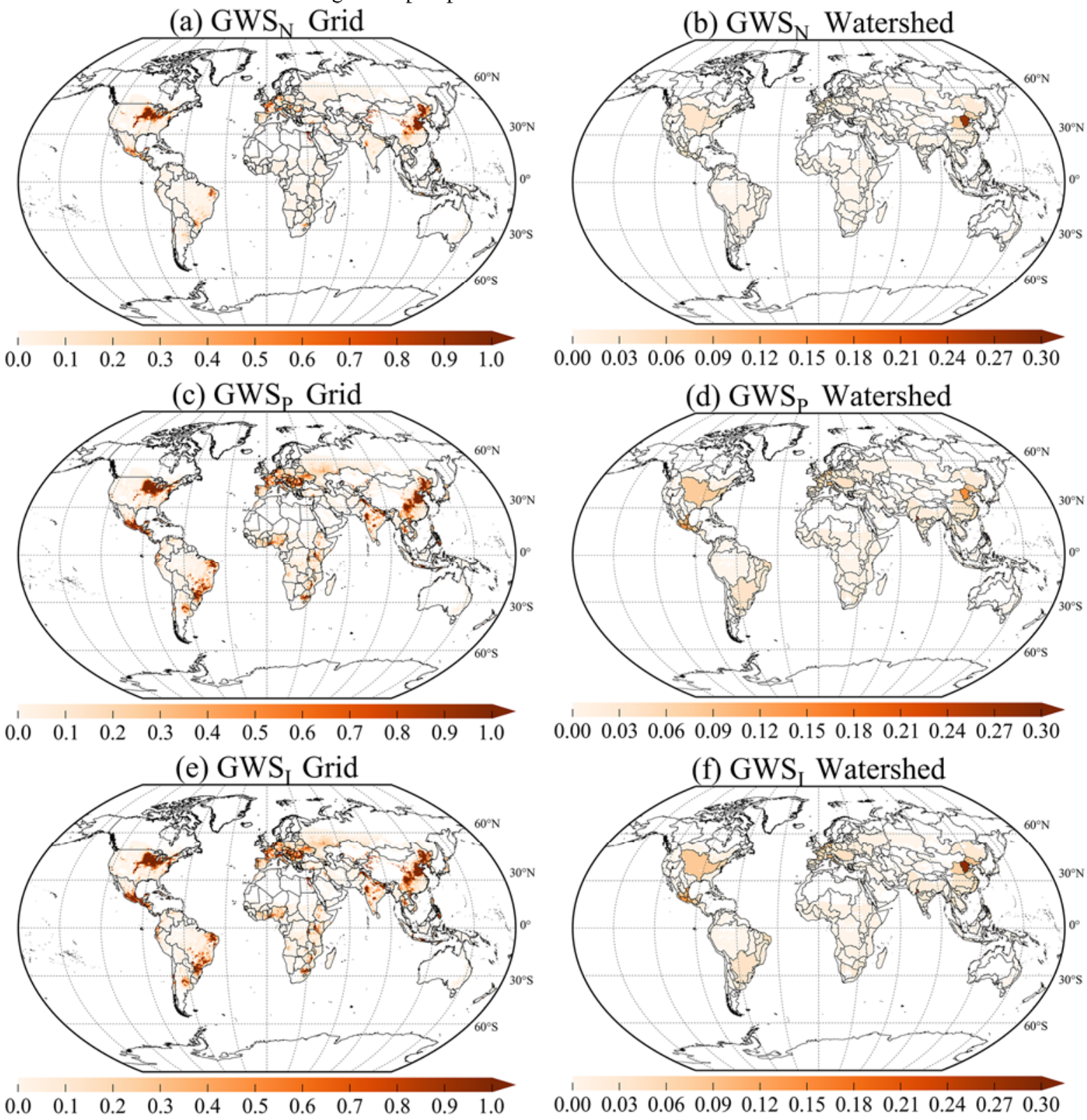
Fig. 3 Fraction of grid number with grey water stress (GWS) higher than 1 in total grid number of maize cultivation. For $\mathrm{X}$ axis, N10_0.4 refers to GWS related to $\mathrm{N}\left(\mathrm{GWS}_{\mathrm{N}}\right)$ with $10 \mathrm{mg} \mathrm{N} \mathrm{L}^{-1}$ and $0.4 \mathrm{mg} \mathrm{N} \mathrm{L}^{-1}$ as standard and natural concentration; N3_0.4 refers to $\mathrm{GWS}_{\mathrm{N}}$ with $3 \mathrm{mg} \mathrm{N} \mathrm{L}^{-1}$ and $0.4 \mathrm{mg} \mathrm{N} \mathrm{L}^{-1}$ as standard and natural concentration; N3_0 refers to GWS $\mathrm{S}_{\mathrm{N}}$ with $10 \mathrm{mg} \mathrm{N} \mathrm{L}^{-1}$ and $0 \mathrm{mg} \mathrm{N} \mathrm{L}^{-1}$ as standard and natural concentration; P0.15_0.01 refers to GWS related to P (GWSp) with 0.15 $\mathrm{mg} \mathrm{P} \mathrm{L}{ }^{-1}$ and $0.01 \mathrm{mg} \mathrm{P} \mathrm{L}^{-1}$ as standard and natural concentration; $\mathrm{P} 0.15 \_0$ refers to GWSP with $0.15 \mathrm{mg} \mathrm{P} \mathrm{L}^{-1}$ and $0 \mathrm{mg} \mathrm{P}$ $\mathrm{L}^{-1}$ as standard and natural concentration; Integration is integrated $\mathrm{GWS}\left(\mathrm{GWS}_{\mathrm{I}}\right)$ with $3 \mathrm{mg} \mathrm{N} \mathrm{L}^{-1}$ and $0.15 \mathrm{mg} \mathrm{P} \mathrm{L}^{-1}$ as the standards, and $0.4 \mathrm{mg} \mathrm{N} \mathrm{L}^{-1}$ and $0.01 \mathrm{mg} \mathrm{P} \mathrm{L}^{-1}$ as natural concentrations for $\mathrm{N}$ and $\mathrm{P}$.

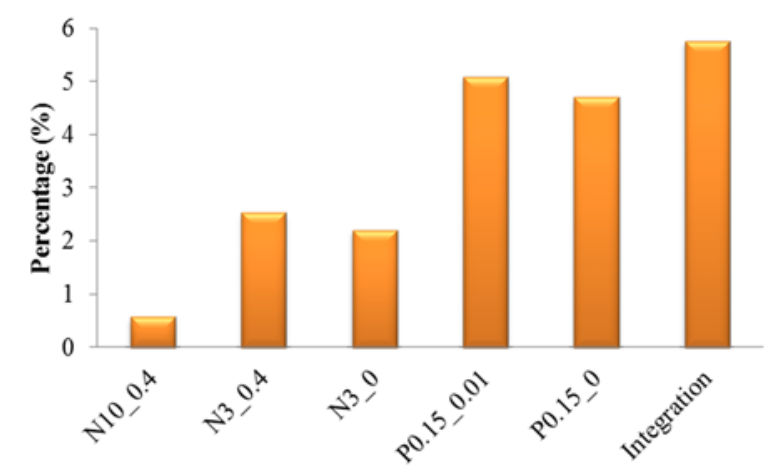

